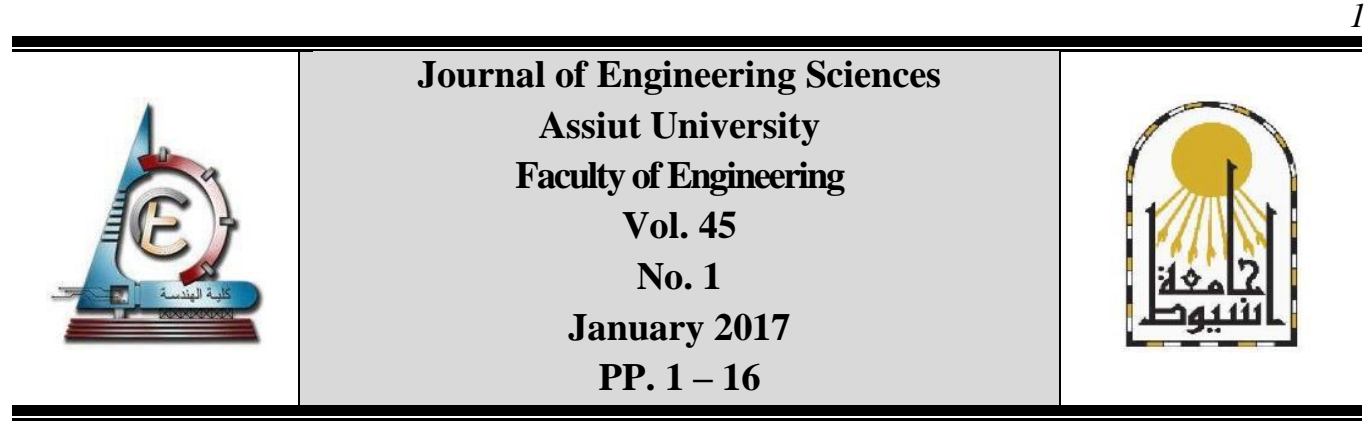

\title{
FATE OF HEAVY METALS AND NUTRIENTS IN WASTE STABILIZATION PONDS IN ARID ZONES
}

\author{
Ali A.M. Gad * and Ahmed M. A. Abdalla \\ ${ }^{1}$ Civil Engineering Department, Faculty of Engineering, Assiut University, Assiut 71516, Egypt
}

Received 16 October 2016; Accepted 19 November 2016

\begin{abstract}
An existing system of natural waste stabilization ponds (WSPs) in El-Qusiyyah city, Upper Egypt was monitored through one year to evaluate the fate of heavy metals and nutrients included in wastewater. The plant treats domestic wastewater with design daily flow rate of $40,000 \mathrm{~m}^{3}$ and stills hydraulically under-loaded. It comprises two parallel lines each consists of anaerobic, facultative, and four maturation ponds in series. Variations of some physicochemical parameters $\left(T, p H, D O, B O D_{5}\right.$, and TSS ) along the ponds system were observed and evaluated. Evaporated water from ponds and its impacts were assessed. Concentration changes of four heavy metal ions $\left(\mathrm{Al}^{3+}, \mathrm{Zn}^{2+}, \mathrm{Cr}^{6+}\right.$, and $\left.\mathrm{Cu}^{2+}\right)$ and various forms of nutrients (nitrogen and phosphorous) along the treatment line were observed. The treatment plant was found to be working well regarding to the investigated physicochemical parameters. General decrease in heavy metals and nutrients concentration along the wastewater stream in the plant was observed. The overall removal efficiency for $\mathrm{Al}^{3+}, \mathrm{Zn}^{2+}, \mathrm{Cr}^{6+}$, and $\mathrm{Cu}^{2+}$ was found to be $80.62 \%, 69.69 \%, 72.99 \%$, and $71.53 \%$, respectively. The system showed moderate overall removal efficiencies for total nitrogen and phosphorous as $68.56 \%$ and $39.37 \%$, respectively. Based on national and international standards, the results of heavy metals and nutrients out of the treatment plant showed the effluent suitability for agricultural irrigation regarding to the studied parameters.
\end{abstract}

Keywords: Wastewater treatment, Waste stabilization ponds, Heavy metals removal, Nutrients removal, Evaporation in arid zones, Agriculture reuse

\section{Introduction}

Wastewater may contain all kinds of chemical and biological pollutants that include heavy metals, nitrogen, phosphorus, detergents, pesticides, hydrocarbons, viruses, bacteria, and protozoa. Some heavy metals are micronutrients and required in trace amounts by living organisms for their normal metabolic function. At elevated concentrations, they become toxic to microorganisms, higher organisms, and plants [1]. The toxicity of heavy metals in wastewater depends on certain factors like metal species and concentration, $\mathrm{pH}$, sludge concentration, wastewater pollution load [2], and solubility of metal ions [3]. Their presence

\footnotetext{
* Corresponding author.

E-mail address: aligad1964@gmail.com
} 
in wastewater is not only of great environmental concern but also strongly reduces microbial activity, as a result detracting biological wastewater treatment processes [4].

The methods of heavy metals removal are numerous and selection of the appropriate technique depends upon factors such as the particular metal(s) involved, chemical composition of sewage, volume requiring treatment, and level of treatment required. Both physical and chemical processes are employed for heavy metals removal. Such processes include precipitation, ion exchange, oxidation/reduction, ultrafiltration, and many others. In primary treatment much of the particulate-associated metal is removed by sedimentation [5]. Microorganisms offer an alternative to physical/chemical methods for metals removal and recovery. The metabolic activity of microorganisms can result in hydrolysis, precipitation, chelation, biomethylation or volatilization of heavy metals [6].

There are three types of waste stabilization ponds (WSPs) in common use; anaerobic, facultative, and maturation, and these are arranged in series as each has different, but complementary functions. Due to their long hydraulic retention times, they are more resilient to both organic and hydraulic shock loads than other wastewater treatment processes. Moreover, WSPs are the only secondary treatment process that can readily produce effluents safe for reuse in agriculture and aquaculture [7]. Evaporation from wide surfaces of stabilization ponds increases concentrations of dissolved and suspended matters in their effluents [8].

Studies on effectiveness of WSPs for treating heavy metals have been reported and the results were mixed. Removal performances in the range from $32 \%$ to $79 \%$ for heavy metals were reported for lagoon systems [9]. High removal of heavy metals in WSPs for domestic wastewater in Morocco was observed [10]. An insignificant decrease in $\mathrm{Cr}, \mathrm{Cu}$, and $\mathrm{Ni}$ in pulp and paper mill effluent from stabilization ponds treatment system was noticed [11]. WSPs showed their capability for reducing metals to some extent but not at desirable levels for discharge [12]. In contrast, the results of physicochemical parameters and heavy metals out of WSPs showed the effluent suitability for agricultural irrigation [13].

Nutrients are among the key parameters, which define the water quality in surface and subsurface waters [14]. Nutrients removal from wastewater is important before effluent is discharged into receiving water bodies [15] or reused in agriculture or aquaculture. Too much nitrogen $(N)$ in irrigation water can reduce some crop yields, even though there may be a more luxuriant growth of non-useful parts of the crop [7]. Most crops are unaffected by TN content in irrigation water up to $30 \mathrm{mg} \mathrm{TN} / \mathrm{L}$, but sensitive crops can tolerate only up to $5 \mathrm{mg} \mathrm{TN} / \mathrm{L}$ [16]. Nutrients removal taking place in natural ponds includes biological processes, in which diversified groups of organisms are responsible i.e. bacteria, fungi, and algae [17].

Few studies have been conducted to assess the extent of $N$ and $P$ removal in WSPs system [18]. Nutrients removal efficiencies were highly variable, ranging from $9 \%$ to $90 \%$ for domestic sewage ponds [19]. In anaerobic ponds organic nitrogen is hydrolyzed to ammonia and almost there is no reduction in $T N$ content. In facultative and maturation ponds, ammonia is incorporated into new algal biomass. Eventually, algae settle to bottom of the pond; around 20 percent of the algal cell mass is non-biodegradable and nitrogen associated with this fraction remains immobilized in pond sediments. The nitrogen associated with the biodegradable fraction eventually diffuses back into the pond liquid and is recycled into algal cells. At high $\mathrm{pH}$, some ammonia leaves the pond by volatilization [7]. There is a little evidence for nitrification and hence denitrification processes in WSPs, unless wastewater is high in nitrates. In parallel, most operating ponds 
remove little phosphorus [20]. Because there are no mechanisms to remove phosphorus completely from pond systems, any phosphorus removed from the water column has to be stored somewhere. The phosphorous removal processes taking place in ponds include biological processes, in which diversified groups of organisms are responsible. Finally, phosphorus removal is achieved by adsorption to sediment, plant, and bacteria uptake. These removal mechanisms may be somewhat dependent on the form of phosphorus; i.e. ortho-P, poly-P, or organic P [21].

Recently, waste stabilization ponds (WSPs) have been widely used for sewage treatment in Upper Egypt. However, their design has always been based on foreign experiences, using imported design parameters. The principal objective of this study is to understand the behavior of four of the most encountered heavy metal ions $\left(\mathrm{Al}^{3+}, \mathrm{Zn}^{2+}, \mathrm{Cr}^{6+}\right.$, and $\left.\mathrm{Cu}^{2+}\right)$ in an existing system of WSPs that had been constructed in arid zone, and possibly, predict their final fate. In addition, the removal of various forms of nutrients as nitrite, nitrate, total nitrogen, phosphate, and total phosphorous were taken into consideration.

\section{Materials and methods}

\subsection{Description of the stabilization ponds system}

A recent waste stabilization ponds (WSPs) system was constructed in El-Qusiyyah city, Upper Egypt. The plant locates at latitude of $27^{\circ} 27^{\prime} N$, longitude of $30^{\circ} 30^{\prime} E$, and about $146.00 \mathrm{~m}$ above sea level. It serves El-Qusiyyah city and some surrounding villages. Designed to treat domestic wastewater with a main daily flow of $40,000 \mathrm{~m}^{3}$, the treatment plant was commissioned in 2008. The average flow rate through the study period was 23,800 $\mathrm{m}^{3} /$ day and the plant was hydraulically under-loaded $(59.50 \%)$. The head works system consists of a slowdown chamber and two sets of mechanical screens, one is coarse and the other is fine. The system comprises two anaerobic ponds (A1\& A1 $\backslash$ ) in parallel. Their effluent feeds two parallel facultative ponds $\left(F 1 \& F 1^{\searrow}\right)$. Each facultative pond discharges into a series of four maturation ponds ( $M 1 \& M 1 \backslash, M 2 \& M 2 \backslash, M 3 \& M 3 \backslash$, and $M 4 \& M 4 \backslash)$. The ponds layout and flow diagram of wastewater through the pond complex are illustrated in Fig. 1. Wastewater flows between ponds by gravity and all ponds have been lined with impermeable polyvinyl chloride (PVC) membranes to prevent groundwater contamination. The total surface area of ponds is $789,600 \mathrm{~m}^{2}$ with an effective volume of $1,474,800 \mathrm{~m}^{3}$. The design physical and operational characteristics of the plant; effective dimensions, flow rates, and hydraulic retention times (HRT) are given in Table 1. The total design $H R T$ of wastewater in the plant is 37.0 days, while the calculated actual $H R T$ through the observation period was 62.12 days as the plant is under-loaded. 


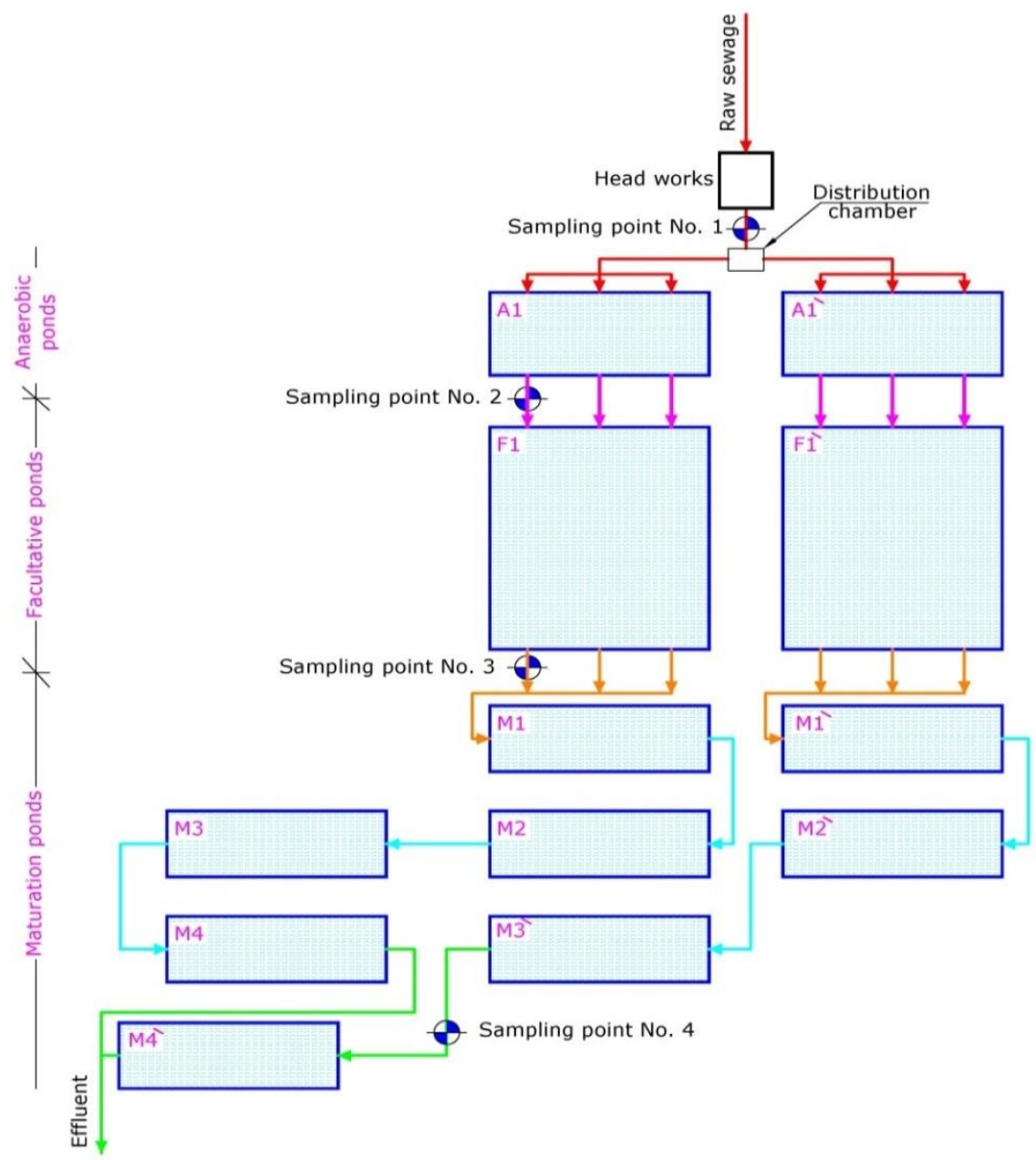

Fig. 1. Schematic flow diagram and layout of El- Qusiyyah waste stabilization ponds.

\section{Table 1.}

Design physical and operational characteristics of El- Qusiyyah WSPs

\begin{tabular}{|l|l|l|l|l|l|}
\hline \multirow{2}{*}{ Ponds } & \multicolumn{4}{l|}{ Effective dimensions } & Design basis \\
\cline { 2 - 6 } & Length $(m)$ & Width $(m)$ & Depth $(m)$ & Flow rate $\left(m^{3} / d\right)$ & $H R T(d)$ \\
\hline A1-A1 $\left.{ }^{\backslash *}\right)$ & 280 & 80 & 4.50 & 20,000 & 3.36 \\
\hline F1-F1 & 810 & 280 & 2.00 & 20,000 & 22.68 \\
\hline M1-M1 & 280 & 130 & 1.50 & 20,000 & 2.73 \\
\hline M2-M2 & 280 & 130 & 1.50 & 20,000 & 2.73 \\
\hline M3-M3 & 280 & 130 & 1.50 & 20,000 & 2.73 \\
\hline M4-M4 & 280 & 130 & 1.50 & 20,000 & 2.73 \\
\hline
\end{tabular}

(*) one third of the depth of anaerobic ponds is assumed to be filled with sludge. $A=$ anaerobic pond, $F=$ facultative pond, $M=$ maturation pond, and $H R T=$ hydraulic retention time. 


\subsection{Measurement and data collection}

Monthly samples were collected from raw sewage and effluents of ponds of ElQusiyyah treatment plant through a complete one year (from January to December 2014). The locations of the sampling points are presented in Fig. 1. Physicochemical parameters of the collected samples such as temperature, $\mathrm{pH}$, dissolved oxygen $(D O)$, unfiltered biochemical oxygen demand $\left(B O D_{5}\right)$, and total suspended solids (TSS) were measured. Concentrations of four heavy metal ions $\left(\mathrm{Al}^{3+}, \mathrm{Zn}^{2+}, \mathrm{Cr}^{6+}\right.$, and $\left.\mathrm{Cu}^{2+}\right)$ were observed though the treatment line. Also, the performance of nitrite-nitrogen $\left(\mathrm{NO}_{2}^{-}-\mathrm{N}\right)$, nitratenitrogen $\left(\mathrm{NO}_{3}^{-}-\mathrm{N}\right)$, total nitrogen $(\mathrm{TN})$, phosphate $\left(\mathrm{PO}_{4}^{3-}\right)$, and total phosphorous (TP) along the treatment process was evaluated. In the present study, all measured values were determined as the means of three replicates and standard errors $( \pm S E)$ were calculated.

\section{Results and discussion}

\subsection{Evaporation from Ponds}

The observed data of several pasting years in Upper Egypt, near to location of the treatment plant indicated that the overall annual evaporation rate from ponds surface is about $5.06 \mathrm{~mm} /$ day [8]. Amounts of the daily evaporated water from anaerobic, facultative, and maturation ponds of El-Qusiyyah treatment plant were calculated, locally from each pond and cumulatively along the treatment line and plotted as illustrated in Fig. 2. Only two thirds of the surface area of anaerobic ponds was considered because a scum layer is covering the remaining area, which effectively prevents significant evaporation. It was found that the amount of the cumulative daily-evaporated water from all ponds is $3,920 \mathrm{~m}^{3} / d$, which represents $16.47 \%$ of the mean daily-flow entering the plant. Thus, the amount of the treated effluent leaving the plant is reduced to be $19,880 \mathrm{~m}^{3} / d$. Accordingly, concentration of substances in the effluent of the plant will increase by $19.72 \%$, percentage by which the amount of wastewater entering the plant exceeds its effluent.

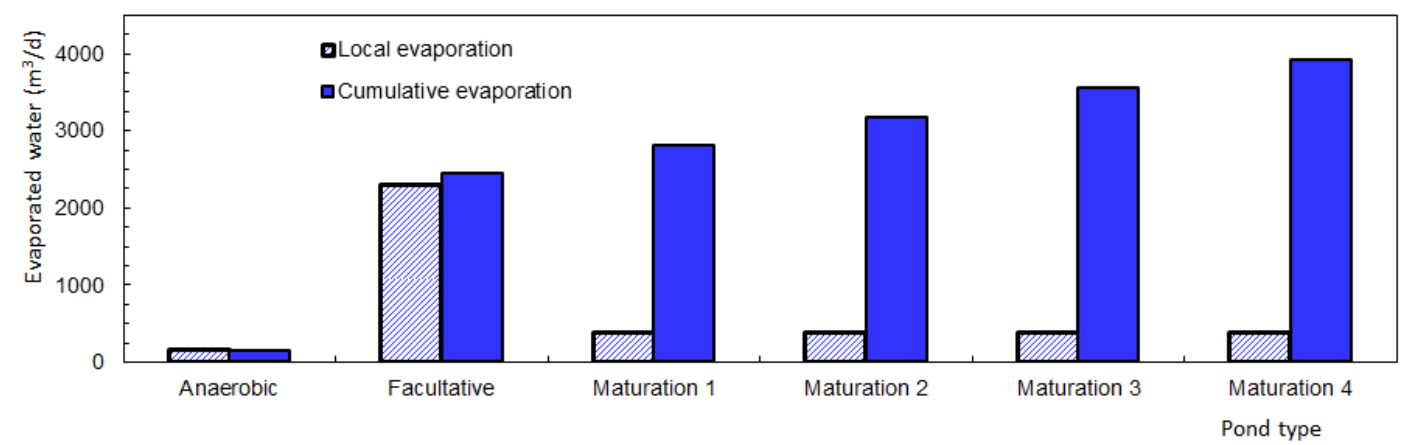

Fig. 2. The mean daily evaporated water from waste stabilization ponds, locally and cumulatively.

\subsection{Actual hydraulic retention times}

Taking the amount of evaporated water from surface of WSPs into consideration, the hydraulic retention time (HRT) of wastewater in each pond in days can be calculated from the following equation:

$$
H R T=\frac{A_{p} D}{Q_{m}}
$$


where $A_{p}$ is the mid-depth pond surface area $\left(\mathrm{m}^{2}\right), \mathrm{D}$ is the pond depth $(\mathrm{m})$, and $Q_{m}$ is the mean flow rate passing the pond $\left(\mathrm{m}^{3} / d\right)$. As $Q_{m}$ is the average of influent $\left(Q_{i}\right)$ and effluent $\left(Q_{e}\right)$ flow rates of the concerned pond, Eq. (1) can be expressed as:

$$
H R T=\frac{A_{p} D}{\left(Q_{i}+Q_{e}\right) / 2}
$$

As the sides and beds of ponds have been lined by polyvinyl chloride (PVC) sheets, there is no seepage, consequently $Q_{e}$ is given by:

$$
Q_{e}=Q_{i}-0.001 E A_{p}
$$

where $E$ is the net evaporation rate $(\mathrm{mm} / \mathrm{d})$. When the value of $Q_{e}$ from Eq. (3) is substituted in Eq. (2), it becomes:

$$
H R T=\frac{2 A_{p} D}{2 Q_{i}-0.001 E A_{p}}
$$

Equation 4 was used to estimate HRT in each pond, for case when the evaporated water from ponds surface is considered. The effects of evaporation from ponds surface on both $\mathrm{Q}_{\mathrm{m}}$ and HRT are summarized in Table 2. As it is observed from the table, the intensive evaporation in such arid regions significantly increases HRT. The overall HRT of wastewater in the plant of El-Qusiyyah increases from 62.12 days to 73.58 days due to the evaporation effect.

\section{Table 2.}

\begin{tabular}{|c|c|c|c|c|}
\hline \multirow[t]{2}{*}{ Pond } & \multicolumn{2}{|c|}{ Without evaporation } & \multicolumn{2}{|c|}{ With evaporation } \\
\hline & $Q_{m}\left(m^{3} / d\right)$ & $H R T(d)$ & $Q_{m}\left(m^{3} / d\right)$ & $H R T(d)$ \\
\hline$A 1-A l^{(*)}$ & 11,900 & 5.65 & 11,824 & 5.68 \\
\hline$F 1-F 1$ & 11,900 & 38.12 & 10,601 & 42.79 \\
\hline$M 1-M 1$ & 11,900 & 4.59 & 9,269 & 5.89 \\
\hline$M 2-M 2$ & 11,900 & 4.59 & 8,901 & 6.13 \\
\hline$M 3-M 3$ & 11,900 & 4.59 & 8,533 & 6.40 \\
\hline$M 4-M 4$ & 11,900 & 4.59 & 8,164 & 6.69 \\
\hline
\end{tabular}

Evaporation effects on mean flow rates $\left(Q_{m}\right)$ and hydraulic retention times $(H R T)$ for El-Qusiyyah WSPs

(*) one third of the depth of the anaerobic ponds is assumed to be filled with sludge. $A$ $=$ anaerobic pond, $F=$ facultative pond, $M=$ maturation pond, and $H R T=$ hydraulic retention time.

\subsection{Physicochemical parameters}

Although this study concerns with fate of heavy metals and nutrients in WSPs, it is indispensable to check out some physicochemical parameters that play a key role in ponds performance. Annual averages of the monthly measured physicochemical parameters of raw sewage and effluents of El-Qusiyyah WSPs are given in Table 3. The maximum temperature of raw sewage and at different stages of treatment occurred in July while the minimum was in December. As it is noticed from Table 3, wastewater temperature gradually decreased along the treatment line due to the intensive evaporation from wastewater surface in the ponds. 
Ali A.M. Gad and Ahmed M.A. Abdalla, Fate of heavy metals and nutrients in waste stabilization ....

Table 3.

Annual averages of the monthly measured physicochemical parameters of raw sewage and effluents of WSPs

\begin{tabular}{|c|c|c|c|c|c|}
\hline \multirow[t]{2}{*}{ Parameters } & \multirow[t]{2}{*}{ Raw sewage } & \multicolumn{3}{|c|}{ Effluent of ponds } & \multirow{2}{*}{$\begin{array}{l}\text { Overall } \\
\text { efficiency }\end{array}$} \\
\hline & & Anaerobic & Facultative & Maturation & \\
\hline$T\left({ }^{\circ} \mathrm{C}\right)$ & $\begin{array}{l}22.85 \pm 0.13 \\
(18.0-28.0)\end{array}$ & $\begin{array}{l}21.23 \pm 0.10 \\
(16.0-27.0)\end{array}$ & $\begin{array}{l}19.83 \pm 0.20 \\
(14.0-26.0)\end{array}$ & $\begin{array}{l}19.01 \pm 0.41 \\
(13.0-25.0)\end{array}$ & NA \\
\hline$p H$ & $\begin{array}{l}7.49 \pm 0.09 \\
(7.11-7.85)\end{array}$ & $\begin{array}{l}7.88 \pm 0.11 \\
(7.51-8.29)\end{array}$ & $\begin{array}{l}8.36 \pm 0.09 \\
(8.03-8.73)\end{array}$ & $\begin{array}{l}8.76 \pm 0.08 \\
(8.41-9.15)\end{array}$ & NA \\
\hline$D O(m g / l)$ & $\begin{array}{l}0.21 \pm 0.02 \\
(0.08-0.50)\end{array}$ & $\begin{array}{l}0.29 \pm 0.04 \\
(0.01-1.30)\end{array}$ & $\begin{array}{l}4.34 \pm 0.16 \\
(3.21-6.10)\end{array}$ & $\begin{array}{l}6.54 \pm 0.41 \\
(4.79-8.90)\end{array}$ & NA \\
\hline$B O D_{5}(m g / l)$ & $\begin{array}{l}358.25 \pm 4.80 \\
(255.0-495.0)\end{array}$ & $\begin{array}{l}149.42 \pm 4.61 \\
(104.0-223.0)\end{array}$ & $\begin{array}{l}94.33 \pm 4.80 \\
(54.0-141.0)\end{array}$ & $\begin{array}{l}50.17 \pm 4.61 \\
(23.0-78.0)\end{array}$ & $86.0 \%$ \\
\hline$T S S(m g / l)$ & $\begin{array}{l}274.83 \pm 9.45 \\
(157.0-479.0)\end{array}$ & $\begin{array}{l}140.0 \pm 5.84 \\
(98.0-201.0)\end{array}$ & $\begin{array}{l}112.42 \pm 4.08 \\
(78.0-185.0)\end{array}$ & $\begin{array}{l}84.67 \pm 3.82 \\
(35.0-169.0)\end{array}$ & $69.19 \%$ \\
\hline
\end{tabular}

$T=$ wastewater temperature, $p H=$ power of hydrogen, $D O=$ dissolved oxygen, $B O D_{5}$ biochemical oxygen demand, TSS = total suspended solids, and NA = not applicable. The data represent the means $\pm S E, n=3$, and values in parentheses represent the range.

Values of $p H$ in ponds wastewater are important for removing heavy metals. At acidic $\mathrm{pH}$, heavy metals tend to exist as free metal ions while around neutral ( $\mathrm{pH} 6-9)$ some precipitate as hydroxides or other insoluble species if the appropriate co-ion is available [5]. In addition, the principal mechanisms for fecal bacterial removal and photosynthesis activities of algae in WSPs depend on $p H$ [7]. Table 3 reveals continuous increases in $p H$ along the treatment line. In facultative and maturation ponds this rise in $p H$ can be related to the rapid photosynthesis of algae, which consumes $\mathrm{CO}_{2}$ faster than it can be replaced by bacterial respiration; as a result carbonate and bicarbonate ions dissociate. Algae fix the resulting $\mathrm{CO}_{2}$ while hydroxyl ions accumulate so raising $p H$. As given in Table 3, the upper extreme value of $\mathrm{pH}$ range of maturation ponds effluent exceeds 9 , i.e. $\mathrm{pH}$ overtakes 9 through some months of the year. At $p H>9$, fecal bacteria die very quickly and the photosynthesis activity of algae becomes less [22].

A great enhancement in $D O$ concentration along the treatment line is indicated in Table 3 , which can be attributed to the occurring reduction of $B O D_{5}$ load, algal oxygen production, and transformation of oxygen from air through the ponds surface. Mean annual values of the monthly measured unfiltered $B O D_{5}$ in raw sewage and effluents of WSPs are given in Table 3 . Its overall removal efficiency through the treatment system was found to be $86.0 \%$. The individual removal efficiency of the unfiltered $B O D_{5}$ in ponds might decrease or increase depending on the amount of degradable organic matters to the added $B O D_{5}$ from generation of new algal cells. The overall annual removal efficiency of the measured TSS through the system of WSPs was $69.19 \%$ as given in Table 3. It is observed that TSS removal efficiency greatly declines along the water path in ponds. For anaerobic ponds, the high concentration of settleable TSS without new algal cells generation resulted in high removal of TSS. As the water moved through the treatment line, the amount of settleable suspended solids decreased while new cells of algae grew that caused the 
reduced removal efficiencies. In general, the sewage treatment plant was found to be working well regarding to the studied physicochemical parameters.

\subsection{Heavy metals removal}

Heavy metals removal from wastewater has major implications on water reuse schemes. In this study, concentrations of four heavy metal ions $\left(\mathrm{Al}^{3+}, \mathrm{Zn}^{2+}, \mathrm{Cr}^{6+}\right.$, and $\left.\mathrm{Cu}^{2+}\right)$ that frequently encountered in domestic wastewater were monthly measured through one year in raw sewage and effluents from WSPs of El-Qusiyyah treatment plant. Results along with the overall removal efficiency were plotted as shown in Fig. 3a-d. Annual averages, ranges, and removal percentages of the concerned heavy metal ions at various stages of treatment are given in Table 4. From Fig. 3 and Table 4, it is noticed that concentrations of heavy metals effectively declined along wastewater path in the plant. This reduction can be attributed to the occurring increase in $\mathrm{pH}$ along the treatment path so that metals form insoluble precipitates as well as the metabolic activity of microorganisms which accompanied by metals biotransformation. As it can be seen in Fig. 3, there is no clear trend that can reflect seasonal changes whether in metals concentration or in removal efficiency because there are many interrelated and uncontrolled natural factors affecting the ponds performance. The overall efficiency for removing $\mathrm{Al}^{3+}, \mathrm{Zn}^{2+}, \mathrm{Cr}^{6+}$, and $\mathrm{Cu}^{2+}$ in El-Qusiyyah WSPs was found to be $80.62 \%, 69.69 \%, 72.99 \%$, and $71.53 \%$, respectively, as given in Table 4 . These removal percentages are in concomitant with previous studies [23].

Table 4 exhibits local removal efficiencies for heavy metals in anaerobic ponds with values less than those of facultative ponds. In both kinds of ponds, metals were removed by hydroxide precipitation according to $\mathrm{pH}$ of wastewater while facultative ponds have an additional removing mechanism of metabolic activity with metal biotransformation that provided by microorganisms. From Table 4, the local efficiency of heavy metals removal in a single facultative pond is smaller but close to that of combined four maturation ponds. This shortage in the performance of maturation ponds comes from small concentrations of heavy metals and settleable matters reached this kind of ponds and high $\mathrm{pH}$ value of their wastewater that reduces the algal photosynthesis, consequently the metal biotransformation. In general, these results prove that the ponds system effectively removed heavy metals of contaminated sewage originated from domestic wastewater.

\subsection{Nutrients removal}

\subsubsection{Nitrogen removal}

Various forms of nitrogen were analysed to determine its load enters and exits from WSPs of El-Qusiyyah treatment plant. Figure 4a, b shows transient changes of the monthly measured nitrite $\left(\mathrm{NO}_{2}^{-}-\mathrm{N}\right)$ and nitrate $\left(\mathrm{NO}_{3}^{-}-\mathrm{N}\right)$ concentrations through one year at different stages of treatment. In addition, Table 5 gives annual averages and ranges of nitrite and nitrate concentrations along the wastewater stream. From Fig. 4 and Table 5, there is a slight decrease in nitrite beside effective reduction in nitrate concentrations in anaerobic ponds, which might result from anoxic denitrification, which may occur without requiring even a trace of oxygen. In contrast, nitrite and nitrate contents increased significantly as the sewage stream passed the facultative ponds. This increase might result from nitrification processes by nitrifying bacteria in this kind of ponds. Again, these concentrations decreased effectively in maturation ponds effluent due to de-nitrification processes and directly uptake of nitrite and nitrate by algal biomass when the preferred ammoniacal-N is at low level. Along wastewater steam in the plant, concentrations of 
Ali A.M. Gad and Ahmed M.A. Abdalla, Fate of heavy metals and nutrients in waste stabilization ....

nitrite was much less than nitrate due to aeration from the ponds surface besides photosynthesis activity of algae, which increase the oxygen concentration in ponds that helping quick oxidation of $\mathrm{NO}_{2}^{-}$to $\mathrm{NO}_{3}^{-}$.
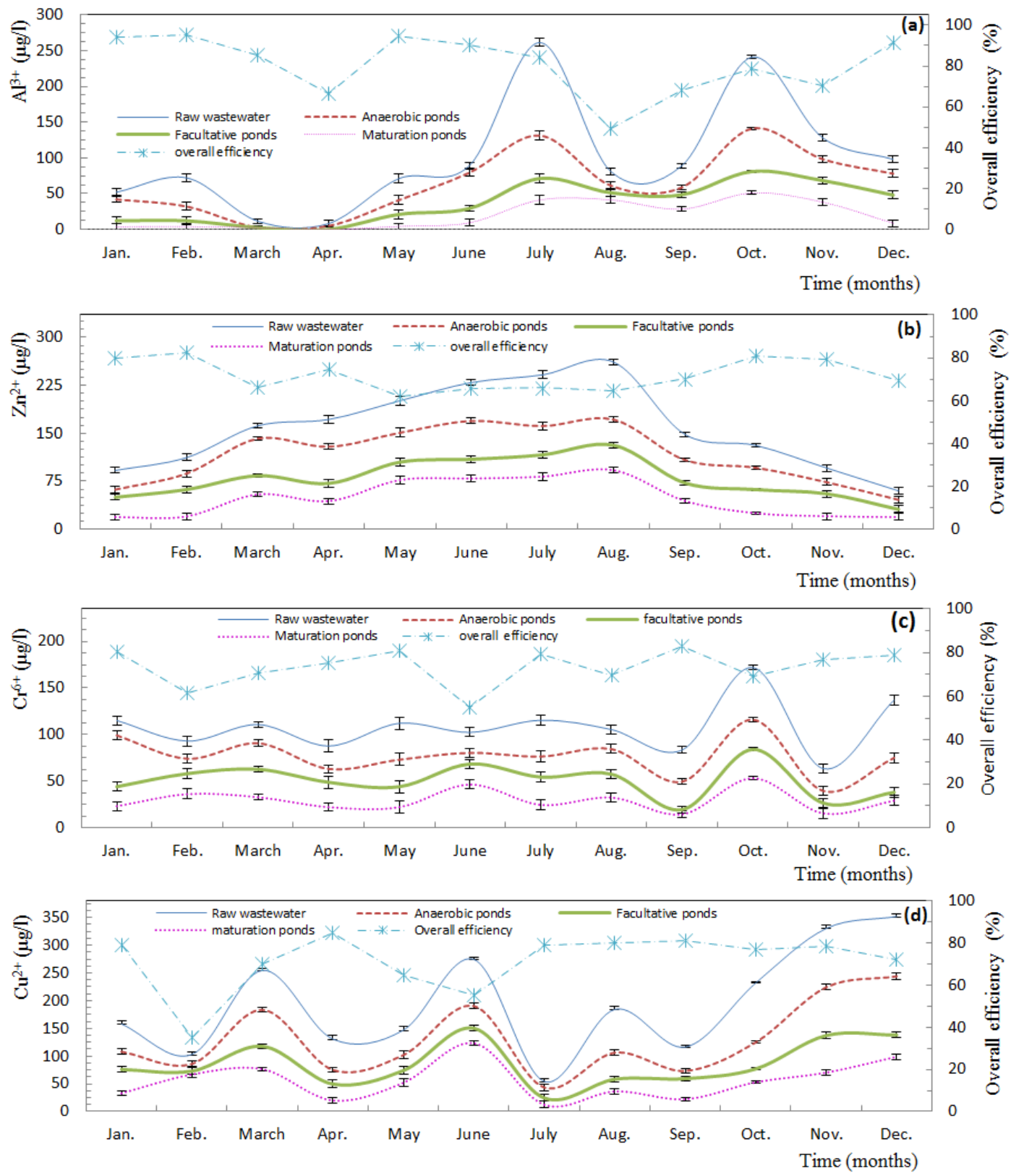

Fig. 3. Transient changes of the measured heavy metal ions concentration and overall removal efficiency through one year at different stages of treatment; (a) aluminium $\left(\mathrm{Al}^{3+}\right)$, (b) zinc $\left(\mathrm{Zn}^{2+}\right)$, (c) chromium $\left(\mathrm{Cr}^{6+}\right)$, and (d) copper $\left(\mathrm{Cu}^{2+}\right)$. The error bars indicate standard errors $(\mathrm{SE})$. The data represent the means $\pm \mathrm{SE}$ and $n=3$. 
Table 4.

Annual averages, ranges, and removal percentages of heavy metal ions at various stages of wastewater treatment

\begin{tabular}{|c|c|c|c|c|c|c|c|c|}
\hline \multirow{3}{*}{ Location } & \multicolumn{8}{|c|}{ Concentration and percentages of removal } \\
\hline & \multicolumn{2}{|c|}{ Aluminium $\left(A l^{3+}\right)$} & \multicolumn{2}{|l|}{$\operatorname{Zinc}\left(\mathrm{Zn}^{2+}\right)$} & \multicolumn{2}{|c|}{ Chromium $\left(\mathrm{Cr}^{6+}\right)$} & \multicolumn{2}{|c|}{ Copper $\left(\mathrm{Cu}^{2+}\right)$} \\
\hline & $\mu g / l$ & $\begin{array}{l}\% \\
\text { removed }\end{array}$ & $\mu g / l$ & $\begin{array}{l}\% \\
\text { removed }\end{array}$ & $\mu g / l$ & $\begin{array}{l}\% \\
\text { removed }\end{array}$ & $\mu g / l$ & $\begin{array}{l}\% \\
\text { removed }\end{array}$ \\
\hline$R S$ & $\begin{array}{l}100.19 \pm 4.61 \\
(8.0-261.33)\end{array}$ & & $\begin{array}{l}158.75 \pm 4.80 \\
(60.0-261.33)\end{array}$ & & $\begin{array}{l}108.08 \pm 4.80 \\
(63.33-172.0)\end{array}$ & & $\begin{array}{l}194.75 \pm 4.80 \\
(54.33-352.0)\end{array}$ & \\
\hline AP. Eff. & $\begin{array}{l}64.17 \pm 4.58 \\
(2.67-141.0)\end{array}$ & 35.96 & $\begin{array}{c}116.36 \pm 4.61 \\
(46.0-171.33)\end{array}$ & 26.70 & $\begin{array}{l}76.69 \pm 4.61 \\
(39.33-116.0)\end{array}$ & 29.04 & $\begin{array}{l}130.11 \pm 4.61 \\
(43.33-244.0)\end{array}$ & 33.19 \\
\hline FP. Eff. & $\begin{array}{l}37.11 \pm 4.20 \\
(0.0-81.0)\end{array}$ & 42.16 & $\begin{array}{l}79.17 \pm 4.80 \\
(31.0-131.33)\end{array}$ & 31.96 & $\begin{array}{l}50.42 \pm 4.80 \\
(19.33-84.0)\end{array}$ & 34.26 & $\begin{array}{l}86.25 \pm 4.80 \\
(24.33-150.33)\end{array}$ & 33.71 \\
\hline MP. Eff. & $\begin{array}{l}19.42 \pm 3.75 \\
(0.0-51.0)\end{array}$ & 47.68 & $\begin{array}{l}48.11 \pm 4.61 \\
(19.0-92.33)\end{array}$ & 39.23 & $\begin{array}{l}29.19 \pm 4.61 \\
(14.33-53.0)\end{array}$ & 42.09 & $\begin{array}{l}55.44 \pm 4.61 \\
(12.33-123.33)\end{array}$ & 35.72 \\
\hline $\begin{array}{l}\text { Overall } \\
\text { efficiency }\end{array}$ & $80.62 \%$ & & $69.69 \%$ & & $72.99 \%$ & & $71.53 \%$ & \\
\hline
\end{tabular}

$\mathrm{RS}=$ raw sewage, AP. Eff. = anaerobic pond effluent, FP. Eff. = facultative pond effluent, and MP. Eff. = maturation pond effluent. The data represent the means $\pm \mathrm{SE}, \mathrm{n}=$ 3 , and values in parentheses represent the range.
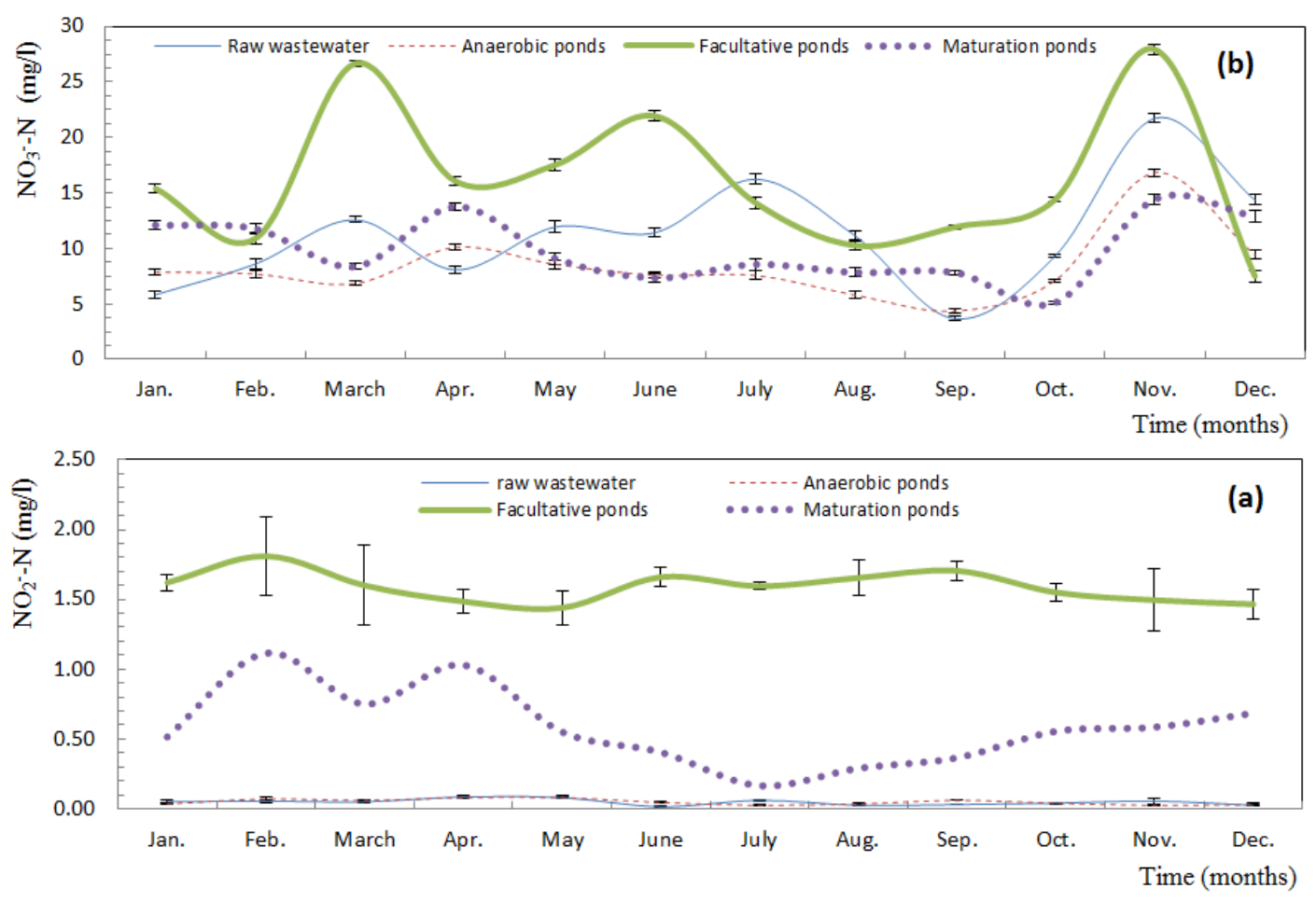

Fig. 4. Transient changes of the measured nitrite and nitrate concentrations through one year at different stages of treatment; (a) nitrite $\left(\mathrm{NO}_{2}^{-}-\mathrm{N}\right)$ and (b) nitrate $\left(\mathrm{NO}_{3}^{-}-\mathrm{N}\right)$. The error bars indicate standard errors (SE). The data represent the means $\pm \mathrm{SE}$ and $n=3$. 
Ali A.M. Gad and Ahmed M.A. Abdalla, Fate of heavy metals and nutrients in waste stabilization ....

\section{Table 5.}

Annual averages and ranges of nitrite and nitrate concentrations along the wastewater stream in the treatment plant

\begin{tabular}{|l|l|l|l|l|}
\hline Parameter & Raw sewage & \multicolumn{3}{|c|}{ Type of pond } \\
\cline { 3 - 5 } & & Anaerobic effluent & Facultative effluent & Maturation effluent \\
\hline $\boldsymbol{N O}_{\mathbf{2}}^{-}-\boldsymbol{N}(m g / l)$ & $0.05 \pm 0.01$ & $0.05 \pm 0.01$ & $1.59 \pm 0.13$ & $0.58 \pm 0.09$ \\
& $(0.02-0.09)$ & $(0.03-0.08)$ & $(1.44-1.81)$ & $(0.17-1.12)$ \\
\hline $\mathbf{N O}_{\mathbf{3}}^{-}-\boldsymbol{N}(\mathrm{mg} / \mathrm{l})$ & $11.24 \pm 0.36$ & $8.31 \pm 0.29$ & $16.22 \pm 0.41$ & $9.93 \pm 0.39$ \\
& $(3.67-21.73)$ & $(4.37-16.83)$ & $(7.50-27.93)$ & $(5.10-14.43)$ \\
\hline
\end{tabular}

The data represent the means $\pm S E, n=3$, and values in parentheses represent the range.

Samples were collected along the treatment line of the plant to check the fate of total nitrogen $(T N)$ in WSPs. Its mean concentration in raw wastewater and effluent of anaerobic ponds was found to be 43.60 and $42.70 \mathrm{mg} / \mathrm{l}$, respectively. In good agreement with previous observations, the results indicate that through anaerobic ponds there is almost no $T N$ removal [24]. In facultative and maturation pond effluents, the measured concentration of $T N$ was found to be 25.3 and $13.71 \mathrm{mg} / \mathrm{l}$, respectively. Hence, the overall removal efficiency of $T N$ by this system of WSPs is $68.56 \%$, which is close to the expected range from $70 \%$ to $90 \%$ [7]. The major processes of $T N$ removal in facultative and maturation ponds include nitrogen assimilation by algal biomass, sedimentation of particulate organic $N$ to pond bottom sludge, nitrification-denitrification, and $\mathrm{NH}_{3}$ volatilization [19]. Volatilization and sedimentation are the major pathways for $N$ removal in WSPs, accounting removal of $70 \%$ and $25 \%$ of $T N$, respectively [25].

\subsubsection{Phosphorous removal}

Variations of the monthly measured phosphate $\left(\mathrm{PO}_{4}^{3-}\right)$ concentration in raw sewage and WSPs effluent through one year in El-Qusiyyah treatment plant are illustrated in Fig. 5. Annual averages and ranges of $\mathrm{PO}_{4}^{3-}$ concentration at various stages of treatment are given in Table 6. Both Fig. 5 and Table 6 indicate continuous effective reduction in $\mathrm{PO}_{4}^{3-}$ concentration through the treatment line. On the other hand, mean concentrations of the measured total phosphorous $(T P)$ in raw sewage, anaerobic, facultative, and maturation ponds were found to be $16.18,15.59,10.61$, and $9.81 \mathrm{mg} / l$, respectively. Accordingly, the overall removal efficiency of $T P$ in the plant is $39.37 \%$. In previous studies, $T P$ removal by WSPs recorded up to $26 \%$ in Morocco and reached to $48 \%$ in Spain [26]. 


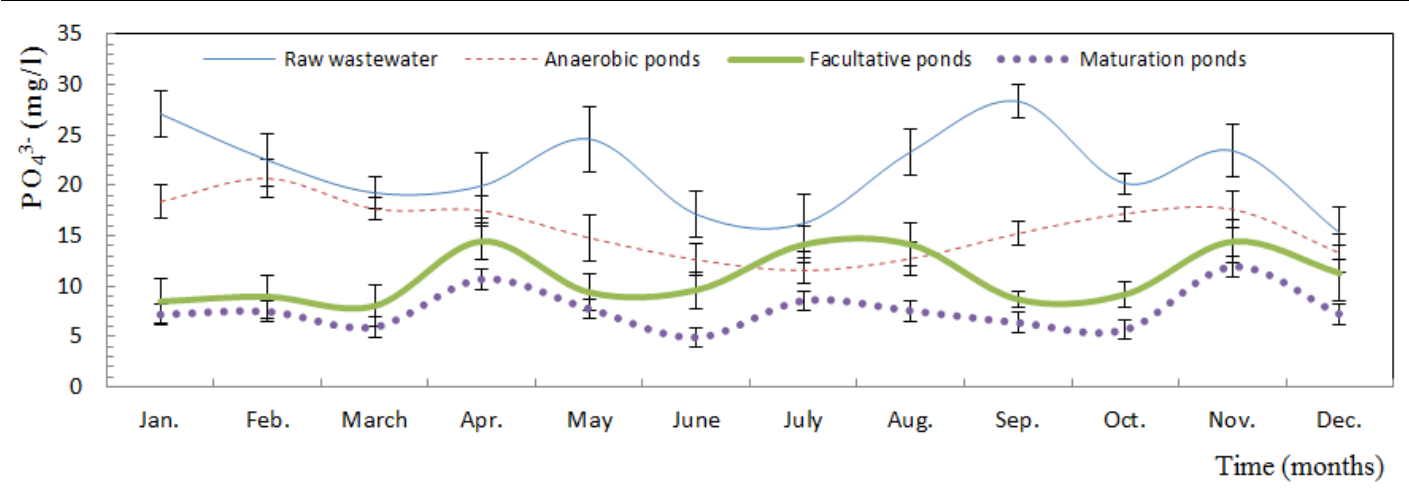

Fig. 5. Variations of the measured phosphate $\left(\mathrm{PO}_{4}^{3-}\right)$ concentration through one year at different stages of treatment. The error bars indicate standard errors (SE). The data represent the means $\pm \mathrm{SE}$ and $\mathrm{n}=3$.

Table 6.

Annual averages and ranges of phosphate $\left(\mathrm{PO}_{4}^{3-}\right)$ concentration at various stages of wastewater treatment

\begin{tabular}{|l|l|l|l|l|}
\hline Parameter & Raw sewage & \multicolumn{3}{|c|}{ Type of pond } \\
\cline { 3 - 5 } & & Anaerobic effluent & Facultative effluent & Maturation effluent \\
\hline $\boldsymbol{P O}_{4}^{3-}(m g / l)$ & $21.45 \pm 2.35$ & $15.78 \pm 1.55$ & $10.91 \pm 1.87$ & $7.62 \pm 0.58$ \\
& $(15.30-28.33)$ & $(11.57-20.70)$ & $(8.07-14.47)$ & $(4.93-11.93)$ \\
\hline
\end{tabular}

The data represent the means $\pm S E, n=3$, and values in parentheses represent the range.

\subsection{Employing the plant effluent to agricultural irrigation}

Water source is one of the limiting factors in arid and semi-arid regions that hinder the development of sustainable agriculture. With correct management of wastewater, some scarcity problems of freshwater can be obviated. Treated wastewater from El-Qusiyyah WSPs system is intended to be used for irrigation. Metals in treated wastewaters significantly increase their content in irrigated soils [27] and they are transferred to plants and food chain [28]. Plants grown in high metals content soils pose a significant human health risk if consumed [29]. Table 7 gives overall annual means of the monthly measured metals and nutrients content in the effluent of El-Qusiyyah WSPs along with their variance range. In addition, applicable national and international guidelines are presented to determine suitability of the plant effluent for agricultural irrigation. The international guidelines were conducted according to U.S. Environmental Protection Agency standards - USEPA [30] while national guidelines were based on the national code of practice - ECP [31].

From Table 7, it is clear that effluent concentrations are below USEPA and ECP guidelines thresholds for short term and long term irrigation with respect to the studied metals $\left(\mathrm{Al}^{3+}, \mathrm{Zn}^{2+}, \mathrm{Cr}^{6+}\right.$, and $\left.\mathrm{Cu}^{2+}\right)$ and nutrients $\left(\mathrm{NO}_{3}^{-}\right.$and $\left.\mathrm{PO}_{4}^{3-}\right)$. Moreover, upper limits of the variance ranges still below the allowable limits of the international and national standards for short and long term irrigation. Accordingly, the effluent of the plant meets the irrigation standards with respect to the concerned parameters all over the year. As most crops are unaffected by total nitrogen $(T N)$ content in irrigation water up to $30 \mathrm{mg} / \mathrm{l}$ while sensitive crops can tolerate only up to $5 \mathrm{mg} / \mathrm{l}$ [16], the effluent of the plant with $T N$ of $13.71 \mathrm{mg} / \mathrm{l}$ can be safely reused for irrigating non-sensitive crops. For 
Ali A.M. Gad and Ahmed M.A. Abdalla, Fate of heavy metals and nutrients in waste stabilization ....

deciding its suitability for restricted or unrestricted irrigation, certain microbiological measurements should be performed.

Table 7.

Comparison of annual averages of metals and nutrients content in the effluent of WSPs with applicable guidelines for agricultural reuse

\begin{tabular}{|l|l|l|l|l|}
\hline Parameter & Effluent & \multicolumn{2}{|l|}{ National guidelines } & \multirow{2}{*}{ USEPA $^{(*)}$} \\
\cline { 3 - 4 } & & Long-term use & Short-term use & \\
\hline Aluminium $(\boldsymbol{\mu g} / \boldsymbol{l})$ & $\begin{array}{l}19.42 \pm 3.75 \\
(0.0-51.0)\end{array}$ & 5,000 & 20,000 & 5,000 \\
\hline Zinc $(\boldsymbol{\mu} \boldsymbol{g} / \boldsymbol{l})$ & $\begin{array}{l}48.11 \pm 4.61 \\
(19.0-92.33)\end{array}$ & 5,000 & 10,000 & 2,000 \\
\hline Chromium $(\boldsymbol{\mu g} / \boldsymbol{l})$ & $\begin{array}{l}29.19 \pm 4.61 \\
(14.33-53.0)\end{array}$ & 100 & 1,000 & 100 \\
\hline Copper $(\boldsymbol{\mu g} / \boldsymbol{l})$ & $\begin{array}{l}55.44 \pm 4.61 \\
(12.33-123.33)\end{array}$ & 200 & 5,000 & 200 \\
\hline $\mathbf{N O}_{\mathbf{2}}^{-}-\mathbf{N}(\mathrm{mg} / \mathrm{l})$ & $\begin{array}{l}9.93 \pm 0.39 \\
(5.10-14.43)\end{array}$ & NR & NR & 30 \\
\hline $\mathbf{P O}_{\mathbf{4}}^{\mathbf{3}}(\mathrm{mg} / \mathbf{l})$ & $\begin{array}{l}7.62 \pm 0.58 \\
(4.93-11.93)\end{array}$ & 30 & 30 & NR \\
\hline
\end{tabular}

* Recommended maximum concentration for crop production (ECP, 2005).

** Recommended maximum concentration for crop production (USEPA, 2012).

$\mathrm{NR}=$ Not required under the reuse program.

\section{Conclusions}

An existing system of waste stabilization ponds (WSPs) in El-Qusiyyah city, Upper Egypt was monitored through one year to assess the fate of four of the most encountered heavy metal ions $\left(\mathrm{Al}^{3+}, \mathrm{Zn}^{2+}, \mathrm{Cr}^{6+}\right.$, and $\left.\mathrm{Cu}^{2+}\right)$ and various forms of nutrients $(N$ and $P)$ through the treatment line. Some physicochemical parameters $\left(T, p H, D O, B O D_{5}\right.$, and $\left.T S S\right)$ that play a key role in ponds performance were investigated. The most important findings are as follows:

(1) Hydraulic retention time (HRT) of wastewater in the plant increased from 37.0 to 62.12 days as the plant was under-loaded. Moreover, intensive evaporation from surface of WSPs in such arid zone consumed $16.47 \%$ of the plant daily-flow and elongated HRT to 73.58 days.

(2) The sewage treatment plant was found to be performing well regarding to the investigated physicochemical parameters.

(3) Concentrations of the studied heavy metal ions were effectively eliminated along the ponds series with the least removal in maturation ponds. The overall removal efficiency for $\mathrm{Al}^{3+}, \mathrm{Zn}^{2+}, \mathrm{Cr}^{6+}$, and $\mathrm{Cu}^{2+}$ was found to be $80.62 \%, 69.69 \%$, $72.99 \%$, and $71.53 \%$, respectively.

(4) Concentrations of nitrite and nitrate slightly decreased in anaerobic ponds, effectively increased in facultative ponds, and again decreased significantly in maturation ponds. Total nitrogen was effectively removed in facultative and maturation ponds with overall removal efficiency of $68.56 \%$ through the plant. 
(5) A continuous significant reduction in phosphate and total phosphorous (TP) contents was observed along the wastewater stream in the plant and the overall removal efficiency of TP was found to be $39.37 \%$.

(6) Concentrations of the concerned heavy metals and nutrients in the plant effluent meet long and short irrigation standards for non-sensitive crops according to national and international guidelines. Additional microbiological measurements are required to decide its suitability for either restricted or unrestricted irrigation.

\section{REFERENCES}

[1] Chowdhury, S., Mazumder, M.J., Al-Attas, O., and Husain, T. (2016). Heavy metals in drinking water: Occurrences, implications, and future needs in developing countries. Science of The Total Environment, 569, 476-488.

[2] Dilek, F. and Yetis, Ü. (1992). Effects of heavy metals on activated sludge process. Water Science and Technology, 26, 801-813.

[3] Sujarittanonta, S. and Sherrard, J.H. (1981). Activated sludge nickel toxicity studies. Journal (Water Pollution Control Federation), 1314-1322.

[4] Waara, K.O. (1992). Effects of copper, cadmium, lead and zinc on nitrate reduction in a synthetic water medium and lake water from northern Sweden. Water research, 26, 355-364.

[5] Mara, D. and Horan, N.J. (2003). Handbook of water and wastewater microbiology: Academic press.

[6] Iverson, W.P. and Brinckman, F.E. (1978). Microbial metabolism of heavy metals. Water pollution microbiology, 2, 201-232.

[7] Mara, D.D. and Pearson, H.W. (1998). Design manual for waste stabilization ponds in Mediterranean countries: Lagoon Technology International Ltda.

[8] Gad, A.M., Ali, A.A., and Gomma, A.M. (2005). 2005 The performance of an existing system of waste stabilization ponds in upper Egypt. In 1 (Ed.) First Ain Shams University International Conference on Environmental Engineering, ASCEE-1 (pp. 207-219) Cairo, Egypt: Ain Shams University.

[9] Hannah, S.A., Austern, B.M., Eralp, A.E., and Wise, R.H. (1986). Comparative removal of toxic pollutants by six wastewater treatment processes. Journal (Water Pollution Control Federation), 27-34.

[10] Toumi, A., Nejmeddine, A., and El Hamouri, B. (2000). Heavy metal removal in waste stabilisation ponds and high rate ponds. Water Science and Technology, 42, 17-21.

[11] Achoka, J. (2002). The efficiency of oxidation ponds at the Kraft pulp and paper mill at Webuye in Kenya. Water research, 36, 1203-1212.

[12] Ogunfowokan, A., Adenuga, A., Torto, N., and Okoh, E. (2008). Heavy metals pollution in a sewage treatment oxidation pond and the receiving stream of the Obafemi Awolowo University, Ile Ife, Nigeria. Environmental monitoring and assessment, 143, 25-41.

[13] Mansouri, B. and Ebrahimpour, M. (2011). Heavy metals characteristics of wastewater stabilization ponds. American-Eurasian Journal of Agricultural and Environmental Sciences, 10, 763-768.

[14] Ak, M. and Gunduz, O. (2013). Comparison of organic matter removal from synthetic and real wastewater in a laboratory-scale soil aquifer treatment system. Water, Air, \& Soil Pollution, 224, 1-16.

[15] Mayo, A.W. and Abbas, M. (2014). Removal mechanisms of nitrogen in waste stabilization ponds. Physics and Chemistry of the Earth, Parts $A / B / C, 72,77-82$.

[16] Ayers, R. and Westcot, D. (1985). Water quality for agriculture. FAO Irrigation and drainage paper 29 Rev. 1. Food and Agricultural Organization. Rome.

[17] Hosetti, B. and Frost, S. (1998). A review of the control of biological waste treatment in stabilization ponds. Critical Reviews in Environmental Science and Technology, 28, 193-218. 
Ali A.M. Gad and Ahmed M.A. Abdalla, Fate of heavy metals and nutrients in waste stabilization ....

[18] Nguyen, M. and Davies-Colley, R. (1998). Nitrogen and phosphorus cycling in waste stabilisation ponds and their influence on the quality of discharged effluents: a review.

[19] Pearson, H., Mara, D., Cawley, L., Arridge, H., and Silva, S. (1996). The performance of an innovative tropical experimental waste stabilisation pond system operating at high organic loadings. Water Science and Technology, 33, 63-73.

[20] Tanner, C., Sukias, J., and Upsdell, M. (1999). Substratum phosphorus accumulation during maturation of gravel-bed constructed wetlands. Water Science and Technology, 40, 147-154.

[21] Strang, T. and Wareham, D. (2006). Phosphorus removal in a waste-stabilization pond containing limestone rock filters. Journal of Environmental Engineering and Science, 5, 447-457.

[22] Abdel-Raouf, N., Al-Homaidan, A., and Ibraheem, I. (2012). Microalgae and wastewater treatment. Saudi Journal of Biological Sciences, 19, 257-275.

[23] Juanico, M., Ravid, R., Azov, Y., and Teltsch, B. (1995). Removal of trace metals from wastewater during long-term storage in seasonal reservoirs. Water, Air, and Soil Pollution, 82, 617-633.

[24] Mara, D. (2013). Domestic wastewater treatment in developing countries: Routledge.

[25] Reed, S.C. (1985). Nitrogen removal in wastewater stabilization ponds. Journal (Water Pollution Control Federation), 39-45.

[26] Mbwele, L. A. (2006). Microbial phosphorus removal in waste stabilisation pond wastewater treatment systems.

[27] Nan, Z., Li, J., Zhang, J., and Cheng, G. (2002). Cadmium and zinc interactions and their transfer in soil-crop system under actual field conditions. Science of The Total Environment, 285, 187-195.

[28] Rattan, R., Datta, S., Chhonkar, P., Suribabu, K., and Singh, A. (2005). Long-term impact of irrigation with sewage effluents on heavy metal content in soils, crops and groundwater-a case study. Agriculture, Ecosystems \& Environment, 109, 310-322.

[29] Voutsa, D., Grimanis, A., and Samara, C. (1996). Trace elements in vegetables grown in an industrial area in relation to soil and air particulate matter. Environmental Pollution, 94, 325-335.

[30] USEPA (2012). U.S. Environmental Protection Agency, Guidelines for Water Reuse, Report EPA/600/R-12/618, Cincinnati, Ohio.

[31] ECP (2005). Egyptian Code of Practice, Reuse of treated wastewater in agricultural irrigation, Ministry of Housing, Utilities and Urban Development, Egypt (In Arabic). 
إزالة المعادن الثقيلة والمغذيات في برك الأكسدة في المناطق القاحلة

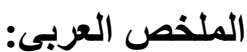

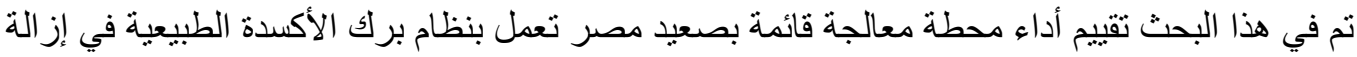

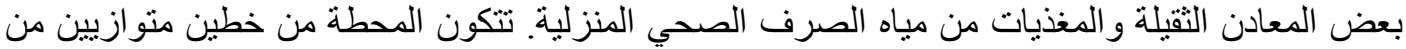

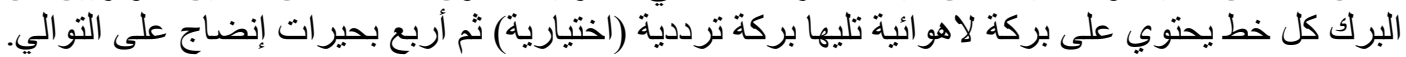

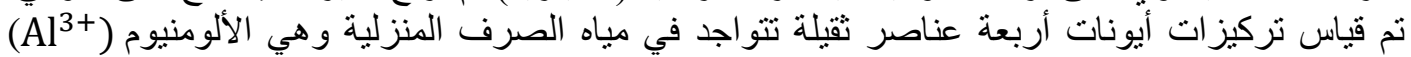
و الزنك (

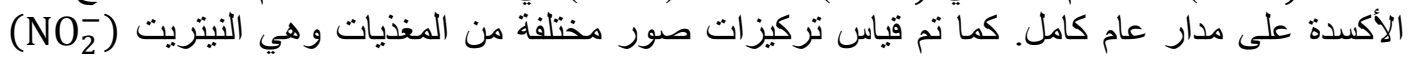
و النيتر ات (

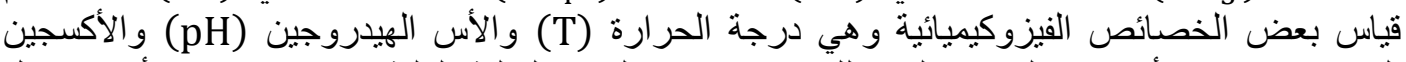
الذائب (DO) و الأكسجين الحيوي المستهلك (BOD أساسية لتفسير نتائج الدر اسة.

وقد أوضحت النتائج أن المحطة تعمل بصورة جيدة بالنسبة للخصائص الفيزوكيميائية التي تم قياسها و أنها

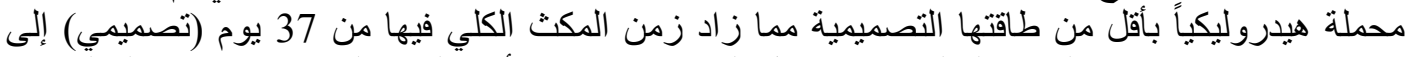

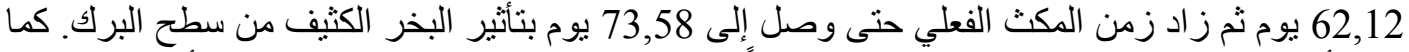

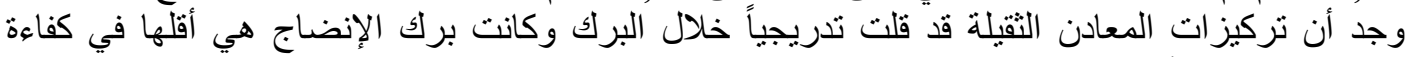

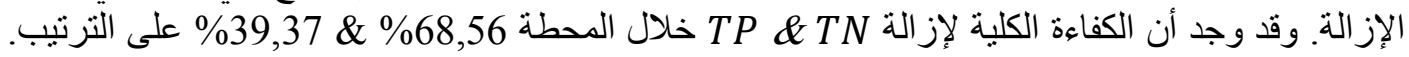

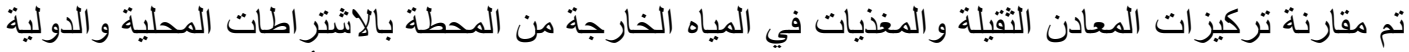

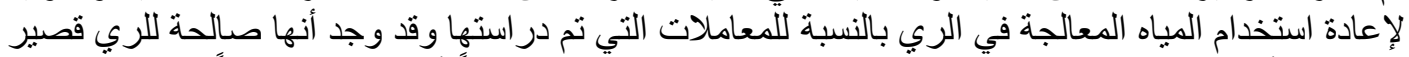

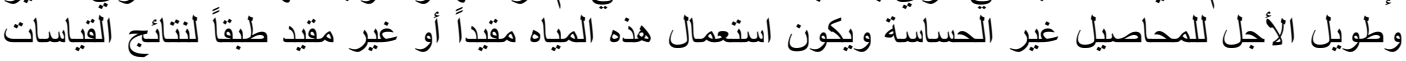
الميكروبيولوجية. 